\title{
Clinical Relevance for Serum Cold-Inducible RNA-Binding Protein Level in Alopecia Areata
}

\author{
Jung-Min Shin*, Jung-Woo Ko*, In Sun Kwon ${ }^{1}$, Jong-Won Choi, Dongkyun Hong, Jin-Hyup Lee, \\ Young-Joon Seo, Chang-Deok Kim, Jeung-Hoon Lee, Young Lee, Kyung-Duck Park ${ }^{\dagger}$ \\ Department of Dermatology, School of Medicine, Chungnam National University, ${ }^{1}$ Clinical Trials Center, Chungnam National University \\ Hospital, Daejeon, Korea
}

Background: Alopecia areata (AA), a chronic, relapsing hairloss disorder, is considered to be a T-cell-mediated autoimmune disease. Cold-inducible RNA-binding protein (CIRP) belongs to a family of cold-shock proteins that respond to cold stress, and has been identified as a damage-associated molecular pattern (DAMP) molecule that triggers the inflammatory response. Recent studies have shown that highmobility group box 1, another DAMP molecule, is elevated in serum and scalp tissue of AA patients, suggesting a relationship between DAMP molecules and the pathogenesis of AA. Objective: To investigate the clinical significance of serum CIRP levels in AA. Methods: The serum levels of CIRP were compared between 68 patients with AA and 20 healthy controls. Additionally, the correlation between CIRP level and various clinical parameters was evaluated. Results: The serum CIRP levels were significantly higher in AA patients compared to healthy subjects. Moreover, there was an association between the serum CIRP level and clinical characteristics, such as disease duration and disease activity. How-

Received August 27, 2018, Revised December 10, 2018, Accepted for publication January 10, 2019

${ }^{\dagger}$ Current affiliation: Kyung-Duck Park, Department of Dermatology, Kyungpook National University School of Medicine, Daegu, Korea

Corresponding author: Kyung-Duck Park, Department of Dermatology, Chungnam National University Hospital, 282 Munhwa-ro, Jung-gu, Daejeon 35015, Korea. Tel: 82-42-280-7700, Fax: 82-42-280-8459, E-mail: gdpk1217@naver.com

ORCID: https://orcid.org/0000-0002-6067-7262

*These authors contributed equally for this study.

This is an Open Access article distributed under the terms of the Creative Commons Attribution Non-Commercial License (http://creativecommons. org/licenses/by-nc/4.0) which permits unrestricted non-commercial use, distribution, and reproduction in any medium, provided the original work is properly cited.

Copyright (c) The Korean Dermatological Association and The Korean Society for Investigative Dermatology ever, there was no significant difference in the serum CIRP level among the clinical types of AA (AA multiplex, alopecia totalis, and alopecia universalis). Conclusion: These results suggest that CIRP may play a significant role in the pathogenesis of $\mathrm{AA}$ and could be a potential biologic marker for monitoring the disease activity of AA. (Ann Dermatol 31(4) $387 \sim 392,2019$ )

\section{-Keywords-}

Alopecia areata, Autoimmune diseases, Inflammation, RNA-binding proteins

\section{INTRODUCTION}

Alopecia areata (AA) is a chronic inflammatory disease characterized by well-circumscribed oval or round bald patches $^{1}$. Although the pathogenesis of AA has yet to be elucidated, it is considered to be an autoimmune disease caused by autoreactive CD8 + T-cells with hair follicle immune privilege collapse ${ }^{1,2}$. Previous studies have reported an association between AA and various autoimmune diseases, such as autoimmune thyroiditis, lupus erythematosus, and rheumatoid arthritis (RA) $)^{3-5}$. Moreover, there is accumulating evidence that AA is a tissue-specific autoimmune disease ${ }^{6,7}$.

Cold-inducible RNA-binding protein (CIRP) belongs to the family of cold-shock proteins that respond to cold stresses. CIRP is a 172-amino-acid molecule that consists of one amino-terminal consensus sequence RNA-binding domain, and is known to be constitutively but weakly expressed in various tissues $^{8-11}$. Under stress conditions, such as hypothermia, hypoxia, and exposure to ultraviolet irradiation, CIRP is upregulated and migrates from the nucleus to the 
cytoplasm, where it promotes the translation of target messenger RNAs ${ }^{12-14}$. Recent studies have focused on the emerging role of CIRP, as a damage-associated molecular pattern molecule (DAMP), in triggering the inflammatory response $^{8,15}$. Qiang et al. ${ }^{8}$ reported that CIRP induces inflammation by promoting secretion of tumor necrosis factor alpha (TNF- $\alpha$ ) and the high-mobility group box 1 (HMGB1) protein in sepsis and hemorrhagic shock. Fein and Calalang-Colucci ${ }^{15}$ demonstrated that CIRP increases caspase- 1 and interleukin (IL)- $1 \beta$, and induces pyroptosis in mouse lung vascular endothelial cells. Recently, the role of these DAMPs and cytokines was highlighted in the pathogenesis of $A A^{16-18}$. In addition, the serum and synovial levels of CIRP were increased, and correlated well with disease activity in patients with RA, an autoimmune disease $^{19}$. Therefore, it could be hypothesized that CIRP plays a significant role in the pathogenesis of AA.

However, the involvement of CIRP in AA has not yet been elucidated. The aim of this study was to compare CIRP levels in patients with AA and healthy controls, and to investigate the clinical significance of serum CIRP levels in AA.

\section{MATERIALS AND METHODS}

\section{Patients}

Blood samples were collected from 68 patients with AA and 20 healthy controls. The control group had no history of AA. To assess the correlation between clinical characteristics and CIRP levels, a medical chart review was conducted to collect clinical data such as patient age, disease type, treatment history, disease duration, and disease activity at the time of blood sampling. The disease activity of AA patients was determined based on hair pull test results. To perform this test, the examiner grasped 50 to 60 hairs and then pulled firmly on the bundle from the base of the hairs using slow traction. When more than $10 \%$ of the hairs were pulled away from the scalp, the hair pull test was considered positive. To analyze the serum level of CIRP according to disease activity, the hair pull test was performed at the same time as the serum samples were taken. Patients with a history of systemic disease known to increase CIRP levels, such as autoimmune disease, infectious disease, and malignancy, were excluded from the study. Informed consent was obtained from each participant. This study received ethical approval from the Institutional Review Board at Chungnam National University, Daejeon, Korea (CNUH-IRB-2018-07-065).

\section{Sample preparation}

Venous blood samples were obtained under sterile con- ditions from all subjects and centrifuged for 15 minutes at

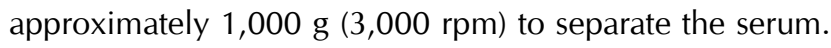
Serum samples were stored at $-20^{\circ} \mathrm{C}$ or $-80^{\circ} \mathrm{C}$ before assaying.

\section{Immunohistochemistry}

Tissue samples were taken from the patients of $\mathrm{AA}$ and healthy controls. Tissue samples were fixed with $10 \%$ formaldehyde, embedded in paraffin, and cut into $4-\mu \mathrm{m}$ thick sections. The sections were deparaffinized in xylene and then rehydrated using an alcohol series. The primary antibody was diluted at a ratio of 1:100 (CIRP antibody; Abcam, Cambridge, UK) and incubated overnight at $4{ }^{\circ} \mathrm{C}$. The sections were then incubated with a secondary antibody at room temperature for 30 minutes. Finally, the sections were incubated with a diaminobenzidine tetrachloride solution at room temperature for 30 seconds and counterstained with Mayer's hematoxylin.

\section{Enzyme-linked immunosorbent assay analysis of serum CIRP levels}

CIRP levels were measured using an enzyme-linked immunosorbent assay kit (Cusabio Biotech, Wuhan, China). Measurements were performed according to the manufacturer's instructions.

\section{Statistical analysis}

All statistical analyses were performed using IBM SPSS Statistics for Windows software (ver. 20.0; IBM Corp., Armonk, NY, USA). The Mann-Whitney $U$ test was used to compare serum CIRP levels between the AA and healthy control groups, and to analyze the correlation with various clinical characteristics, such as age, disease duration, hair pull test results, and treatment history. The Kruskal-Wallis test was used to examine the relationship between the AA types and serum CIRP levels. A $p$-value $<0.05$ was considered to indicate statistical significance.

\section{RESULTS}

\section{Characteristics of patients}

In total, 68 AA patients and 20 healthy individuals were enrolled in this study. The mean age of the patients was 35.5 years (range, $11 \sim 71$ years). The patients were treated with intralesional corticosteroid, topical glucocorticoids, systemic immunosuppressant, or ultraviolet phototherapy. Twelve patients were diagnosed with $\mathrm{AA}$ at the time of blood collection. The demographic data and characteristics of the enrolled AA patients are illustrated in Table 1. 


\section{Expression of CIRP in AA scalp specimens}

The expression of CIRP in the scalp lesions of patients with AA was compared to that in normal scalp skin. CIRP was mainly expressed in the nuclei of hair follicle cells in both normal hair and AA scalp specimens. There was no significant difference in CIRP expression between normal hair and AA scalp specimens (Fig. 1).

Table 1. Characteristics of patients with alopecia areata

\begin{tabular}{lc}
\hline \multicolumn{1}{c}{ Characteristic } & Value \\
\hline All patients & $68(100.0)$ \\
Age (yr) & $35.5 \pm 14.4$ \\
Sex & $37(54.4)$ \\
$\quad$ Male & $31(45.6)$ \\
$\quad$ Female & \\
Type & $20(29.4)$ \\
$\quad$ Alopecia areata multiplex & $32(47.1)$ \\
Alopecia totalis & $16(23.5)$ \\
Alopecia universalis & \\
Onset (mo) & $54(79.4)$ \\
$\leq 6$ & $14(20.6)$ \\
$>6$ & $50(73.5)$ \\
Hair-pull test & $18(26.5)$ \\
Positive & \\
Negative & $21(30.9)$ \\
Treatment history & $28(41.2)$ \\
$\quad$ None & $19(27.9)$ \\
$\quad$ Topical steroid &
\end{tabular}

Values are presented as number (\%) or mean \pm standard deviation.

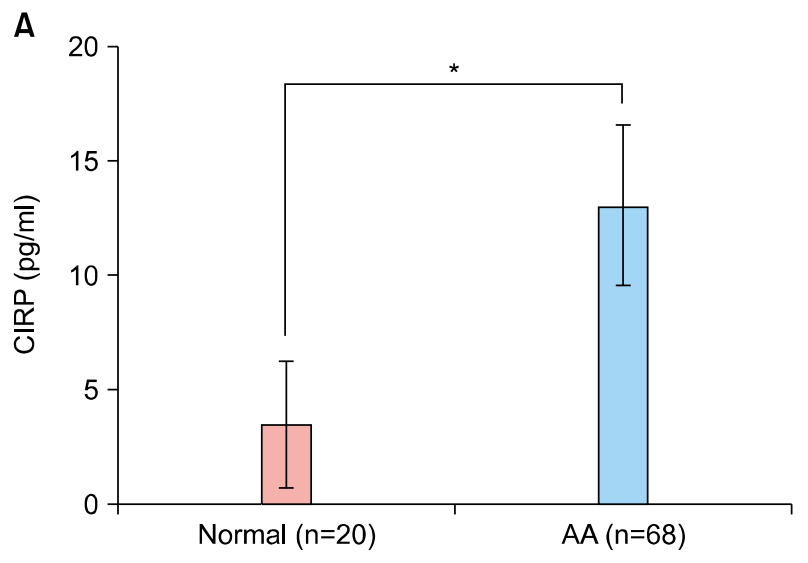

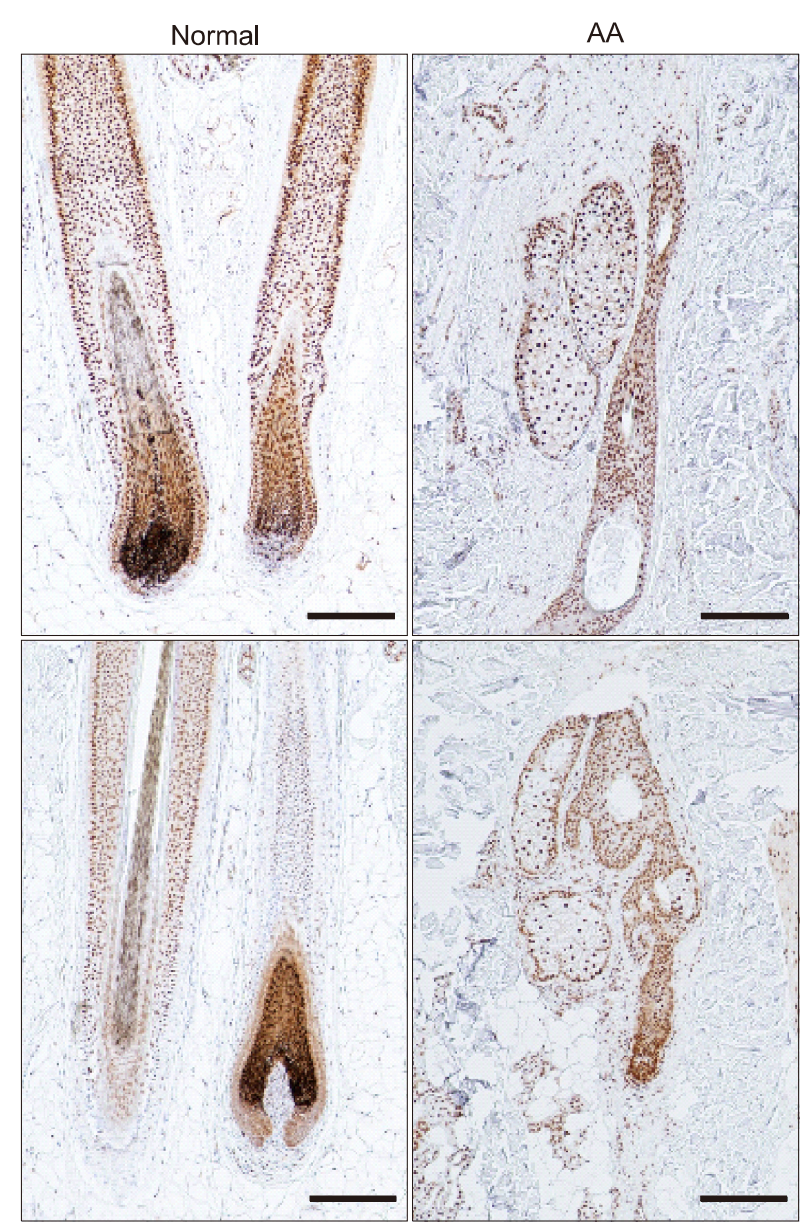

Fig. 1. Expression of cold-inducible RNA-binding protein (CIRP) in normal and alopecia areata (AA)-affected scalp tissues. Paraffin-embedded normal scalp skin and AA lesions were immunohistochemically stained with anti-CIRP (original magnification, $\times 100$; scale bar $=100 \mu \mathrm{m}$ ).

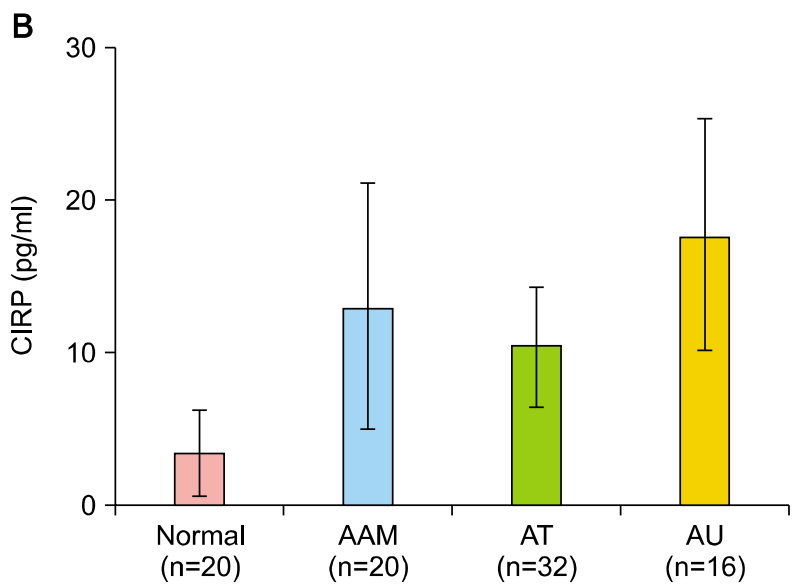

Fig. 2. Serum cold-inducible RNA-binding protein (CIRP) levels in alopecia areata (AA) patients and healthy controls. (A) Serum CIRP level was significantly higher in AA patients than in healthy controls. $p=0.029,{ }^{*} p<0.05$. (B) There was no correlation with AA type. $p=0.707$. AAM: AA multiplex, AT: alopecia totalis, AU: alopecia universalis. 


\section{Elevated serum CIRP levels in AA patients}

Serum CIRP levels were measured using an enzymelinked immunosorbent assay kit. The serum CIRP level in AA patients was significantly higher than that in healthy controls (AA patients, $13.58 \pm 3.52 \mathrm{pg} / \mathrm{ml}$; controls, $3.40 \pm$ $2.79 \mathrm{pg} / \mathrm{ml} ; p=0.029$ ) (Fig. 2A). Additionally, the differences in serum CIRP level according to type of AA (AA multiplex, alopecia totalis, and alopecia universalis) were examined and no significant difference was found ( $p=$ 0.707) (Fig. 2B).

\section{Correlations between serum CIRP levels and clinical characteristics}

The relationship between serum CIRP levels and clinical markers such as age, treatment history, disease activity, and duration was analyzed in patients with AA. The mean serum CIRP level was elevated in patients younger than 18 years of age, but not significantly $(33.67 \pm 14.54 \mathrm{pg} / \mathrm{ml}$ vs. $8.09 \pm$ $2.22 \mathrm{pg} / \mathrm{ml}, p=0.275$ ) (Fig. 3A). Moreover, there was no significant difference in serum CIRP level between the treatment-naïve and treatment-experienced groups (12.94 \pm $4.06 \mathrm{pg} / \mathrm{ml}$ vs. $12.99 \pm 4.69 \mathrm{pg} / \mathrm{ml}, p=0.188$ ) (Fig. 3B). However, the mean serum CIRP level was significantly higher in patients with a positive hair pull test $(15.96 \pm$ $4.51 \mathrm{pg} / \mathrm{ml}$ vs. $4.70 \pm 3.11 \mathrm{pg} / \mathrm{ml}, p=0.048$ ) (Fig. 3C). In addition, the serum CIRP level was significantly elevated in patients experiencing acute disease. The mean serum CIRP level in patients with a disease duration of less than 6 months was significantly higher than that in patients with a disease duration of more than 6 months (16.12 \pm $4.26 \mathrm{pg} / \mathrm{ml}$ vs. $0.84 \pm 0.67 \mathrm{pg} / \mathrm{ml}, p=0.013$ ) (Fig. 3D).

\section{DISCUSSION}

Although the pathogenesis of AA remains incompletely understood, it is believed to result from autoreactive Tcell-mediated hair follicle destruction" ${ }^{1,2}$. A "swarm of bees" clustering of inflammatory cells, mainly T-cells, is observed in and around the bulb region of hair follicles ${ }^{20}$ and
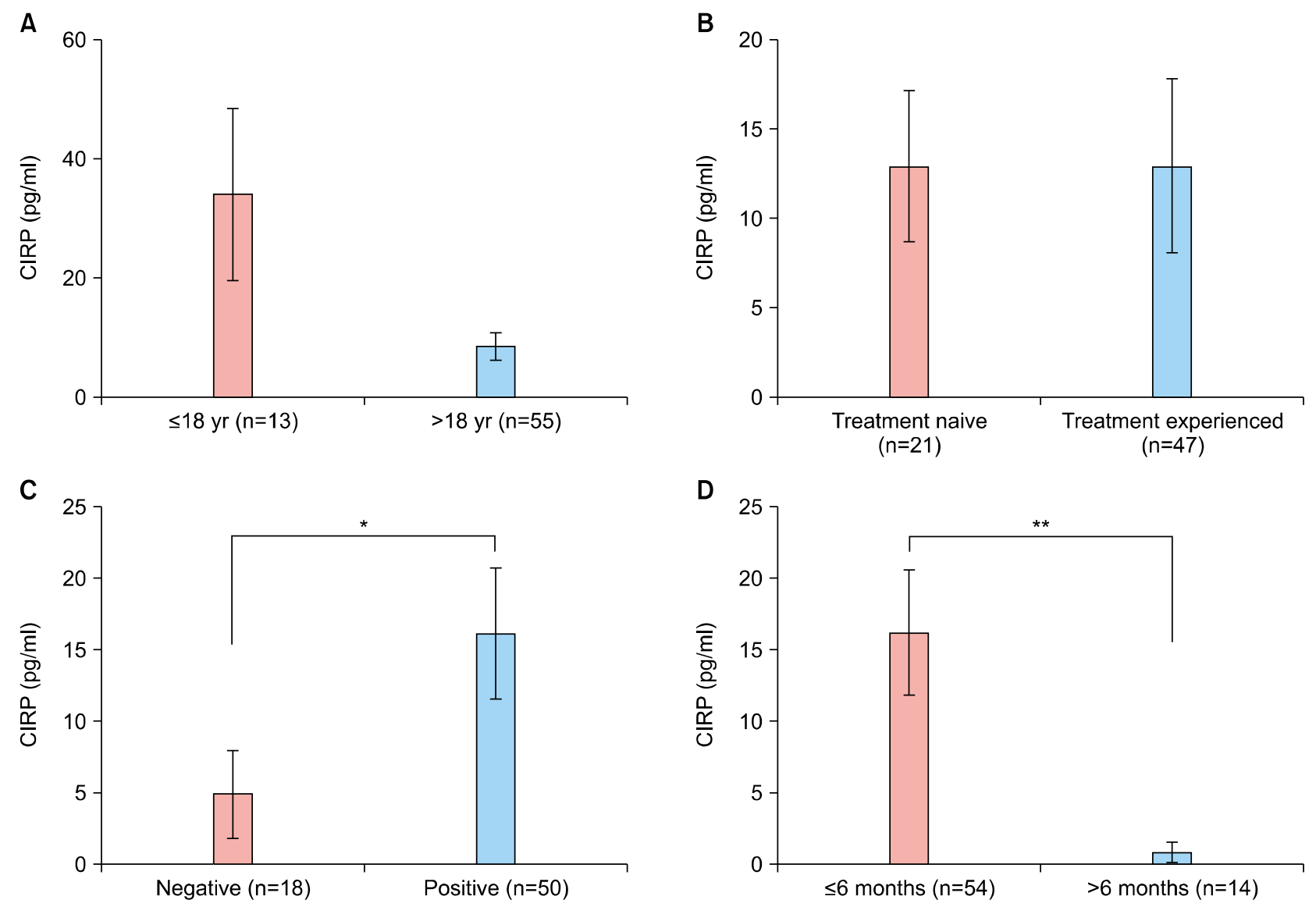

Fig. 3. Serum cold-inducible RNA-binding protein (CIRP) levels according to clinical characteristics. (A, B) There was no significant correlation with patient age $(p=0.275)$ and with treatment experience $(p=0.188)$. (C, D), Significantly higher levels of CIRP were measured in patients with positive hair-pull test results $\left(p=0.048,{ }^{*} p<0.05\right)$ and with acute disease status $(p=0.013, * * p<0.01)$. 
there is a correlation between CD8 + T-cell density and disease severity in $\mathrm{AA}^{21}$. Moreover, multiple lines of evidence have shown that various cytokines play an important role in the cascade of pathogenesis in $A A^{22}$. CIRP, as a novel DAMP molecule, is believed to induce inflammatory responses leading to tissue injury. Recent studies reported that CIRP binds to the TLR4/MD2 complex on both $\mathrm{CD} 8+$ and CD4 + T-cells to induce activation ${ }^{23}$ and stimulates the release of TNF- $\alpha$ and HMGB1 from antigen-presenting cells in sepsis ${ }^{8}$. To obtain new insight into the role of CIRP as a possible key molecule in AA, we compared the serum CIRP levels of patients with AA and healthy controls, and investigated the correlation between the serum CIRP level and clinical characteristics in AA.

In this study, we showed that patients with AA had a significantly higher serum CIRP level than the healthy controls. A previous study showed that CIRP activates inflammation through the NF- $\kappa \mathrm{B}$ protein complex and induces IL-1 $\beta$, IL-8, and TNF- $\alpha$ in cultured fibroblasts ${ }^{24}$. Moreover, recombinant CIRP can induce the release of TNF- $\alpha$, IL-6, and HMGB1 from cultured macrophages ${ }^{8}$. TNF- $\alpha$ and IL-1 are thought to play a key role in the innate immune system and were significantly elevated in the serum samples of AA patients ${ }^{22,25}$. Recent genetic studies of AA have identified a number of genes that regulate acquired and innate immunity, suggesting that multiple factors work together to induce immune dysregulation in the pathogenesis of $\mathrm{AA}^{26,27}$. Thus, CIRP might participate in dysregulation of the innate immune system in AA. Our previous report also revealed that the expression of HMGB1 increases in both the skin and serum samples of AA patients and correlates well with disease severity ${ }^{18}$. Taken together, our results suggest that CIRP is involved in the inflammatory response in the pathogenesis of AA. Unfortunately, we did not check the serum CIRP level after treatment. However, we expect that the serum CIRP level will decline in patients after treatment because healthy controls have a low serum CIRP levels than patients of AA significantly. More studies are needed to verify this.

With regard to the association between the mean serum CIRP level and various clinical characteristics in AA, we found that the serum CIRP level was significantly elevated in groups with more acute disease and positive hair pull test results. Yoo et al. ${ }^{19}$ reported that the synovial CIRP levels in RA patients closely correlated with disease activity, suggesting that CIRP is a potential marker for disease activity in RA. RA is an autoimmune disorder and its association with AA has been reported in several epidemiological and genetic studies ${ }^{5,26}$. Thus, our results imply that CIRP is a promising marker of disease activity in AA.
Recent studies showed that CIRP induces caspase- 1 and IL-1 $\beta$ expression through activation of the NLRP3 inflammasome assembly in mouse lung vascular endothelial cells, and causes significant lung damage in pulmonary inflammation ${ }^{15,28}$. Previously, we investigated the constitutive expression of NLRP3 inflammasomes, and secretion of IL-1 $\beta$ and HMGB1, in human outer root sheath cells of hair follicles ${ }^{29}$. Thus, we hypothesize that elevated serum CIRP might activate NLRP3 inflammasomes in the hair follicle, and then induce secretion of inflammatory cytokines such as IL-1 $\beta$ and HMGB1, contributing to the pathogenesis of AA. Further studies are warranted to confirm our results in skin samples, and to elucidate the location of CIRP expression in the hair follicle, as well as the particular pathway through which CIRP could mediate inflammation and induce hair loss.

In conclusion, this is the first study to investigate the role of CIRP in AA. The serum CIRP levels were higher in patients with $A A$ and were significantly correlated with disease activity. These results suggest that CIRP serves as an inflammatory mediator in AA. To elucidate the exact role of CIRP in the pathogenesis of AA, further studies with larger numbers of patients, and in vitro studies, are needed to clarify the clinical significance of CIRP levels in AA. This study could result in the identification of a useful marker for disease activity in AA and identification of a new therapeutic target for AA.

\section{ACKNOWLEDGMENT}

This research was supported by Basic Science Research Program through the National Research Foundation of Korea (NRF) funded by the Ministry of Education, Science and Technology (2018R1D1A1B07047663).

\section{CONFLICTS OF INTEREST}

The authors have nothing to disclose.

\section{ORCID}

Jung-Min Shin, https://orcid.org/0000-0001-7465-5243 Jung-Woo Ko, https://orcid.org/0000-0002-3479-6305 In Sun Kwon, https://orcid.org/0000-0002-1723-436X Jong-Won Choi, https://orcid.org/0000-0001-9994-8819 Dongkyun Hong, https://orcid.org/0000-0002-4244-0691 Jin-Hyup Lee, https://orcid.org/0000-0002-4903-0900 Young-Joon Seo, https://orcid.org/0000-0002-4955-590X Chang-Deok Kim, https://orcid.org/0000-0001-9341-6491 Jeung-Hoon Lee, https://orcid.org/0000-0002-4869-940X Young Lee, https://orcid.org/0000-0001-9205-1785 
Kyung-Duck Park, https://orcid.org/0000-0002-6067-7262

\section{REFERENCES}

1. Gilhar A, Etzioni A, Paus R. Alopecia areata. N Engl J Med 2012;366:1515-1525.

2. Islam N, Leung PS, Huntley AC, Gershwin ME. The autoimmune basis of alopecia areata: a comprehensive review. Autoimmun Rev 2015;14:81-89.

3. Milgraum SS, Mitchell AJ, Bacon GE, Rasmussen JE. Alopecia areata, endocrine function, and autoantibodies in patients 16 years of age or younger. J Am Acad Dermatol 1987;17: 57-61.

4. Chu SY, Chen YJ, Tseng WC, Lin MW, Chen TJ, Hwang CY, et al. Comorbidity profiles among patients with alopecia areata: the importance of onset age, a nationwide populationbased study. J Am Acad Dermatol 2011;65:949-956.

5. Chen $\mathrm{CH}$, Wang $\mathrm{KH}$, Lin $\mathrm{HC}$, Chung SD. Follow-up study on the relationship between alopecia areata and risk of autoimmune diseases. J Dermatol 2016;43:228-229.

6. Han SS, Seo HM, Kim JS. Comorbid autoimmune diseases among patients with alopecia areata: a population-based case-control study in Korea. Korean J Dermatol 2018;56:3035.

7. McDonagh AJ, Tazi-Ahnini R. Epidemiology and genetics of alopecia areata. Clin Exp Dermatol 2002;27:405-409.

8. Qiang X, Yang WL, Wu R, Zhou M, Jacob A, Dong W, et al. Cold-inducible RNA-binding protein (CIRP) triggers inflammatory responses in hemorrhagic shock and sepsis. Nat Med 2013; 19:1489-1495.

9. Nishiyama H, Itoh K, Kaneko Y, Kishishita M, Yoshida O, Fujita J. A glycine-rich RNA-binding protein mediating coldinducible suppression of mammalian cell growth. J Cell Biol 1997;137:899-908.

10. Nishiyama H, Danno S, Kaneko Y, Itoh K, Yokoi H, Fukumoto $M$, et al. Decreased expression of cold-inducible RNA-binding protein (CIRP) in male germ cells at elevated temperature. Am J Pathol 1998;152:289-296.

11. Nishiyama H, Higashitsuji $H$, Yokoi H, Itoh K, Danno S, Matsuda $T$, et al. Cloning and characterization of human CIRP (cold-inducible RNA-binding protein) CDNA and chromosomal assignment of the gene. Gene 1997;204:115-120.

12. Xue JH, Nonoguchi $K$, Fukumoto $M$, Sato $T$, Nishiyama $H$, Higashitsuji $\mathrm{H}$, et al. Effects of ischemia and $\mathrm{H} 2 \mathrm{O} 2$ on the cold stress protein CIRP expression in rat neuronal cells. Free Radic Biol Med 1999;27:1238-1244.

13. Wellmann $S$, Bührer $C$, Moderegger E, Zelmer A, Kirschner $R$, Koehne $P$, et al. Oxygen-regulated expression of the RNA-binding proteins RBM3 and CIRP by a HIF-1-independent mechanism. J Cell Sci 2004;117(Pt 9):1785-1794.

14. Sheikh MS, Carrier F, Papathanasiou MA, Hollander MC, Zhan Q, Yu K, et al. Identification of several human homologs of hamster DNA damage-inducible transcripts. Cloning and characterization of a novel UV-inducible cDNA that codes for a putative RNA-binding protein. J Biol Chem 1997;272:26720-26726.

15. Fein AM, Calalang-Colucci MG. Acute lung injury and acute respiratory distress syndrome in sepsis and septic shock. Crit Care Clin 2000;16:289-317.

16. Hoffmann R. The potential role of cytokines and T cells in alopecia areata. J Investig Dermatol Symp Proc 1999;4: 235-238.

17. Philpott MP, Sanders DA, Bowen J, Kealey T. Effects of interleukins, colony-stimulating factor and tumour necrosis factor on human hair follicle growth in vitro: a possible role for interleukin-1 and tumour necrosis factor-alpha in alopecia areata. Br J Dermatol 1996;135:942-948.

18. Lee $Y$, Lee HE, Shin JM, Sohn KC, Im M, Kim CD, et al. Clinical significance of serum high-mobility group box 1 level in alopecia areata. J Am Acad Dermatol 2013;69:742747.

19. Yoo IS, Lee SY, Park CK, Lee JC, Kim Y, Yoo SJ, et al. Serum and synovial fluid concentrations of cold-inducible RNAbinding protein in patients with rheumatoid arthritis. Int J Rheum Dis 2018;21:148-154.

20. Messenger AG, Bleehen SS. Alopecia areata: light and electron microscopic pathology of the regrowing white hair. $\mathrm{Br} J$ Dermatol 1984;110:155-162.

21. Jabbari A, Cerise JE, Chen JC, Mackay-Wiggan J, Duvic M, Price $\mathrm{V}$, et al. Molecular signatures define alopecia areata subtypes and transcriptional biomarkers. EBioMedicine 2016;7:240-247.

22. Gregoriou S, Papafragkaki D, Kontochristopoulos G, Rallis E, Kalogeromitros D, Rigopoulos D. Cytokines and other mediators in alopecia areata. Mediators Inflamm 2010;2010: 928030.

23. Bolognese AC, Sharma A, Yang WL, Nicastro J, Coppa GF, Wang P. Cold-inducible RNA-binding protein activates splenic T cells during sepsis in a TLR4-dependent manner. Cell Mol Immunol 2018;15:38-47.

24. Brochu C, Cabrita MA, Melanson BD, Hamill JD, Lau R, Pratt $M A$, et al. NF- $\kappa$ B-dependent role for cold-inducible RNA binding protein in regulating interleukin $1 \beta$. PLoS One 2013;8:e57426.

25. Loh SH, Moon HN, Lew BL, Sim WY. Role of T helper 17 cells and $\mathrm{T}$ regulatory cells in alopecia areata: comparison of lesion and serum cytokine between controls and patients. J Eur Acad Dermatol Venereol 2018;32:1028-1033.

26. Petukhova L, Duvic M, Hordinsky $M$, Norris D, Price V, Shimomura $Y$, et al. Genome-wide association study in alopecia areata implicates both innate and adaptive immunity. Nature 2010;466:113-117.

27. Betz RC, Petukhova L, Ripke S, Huang H, Menelaou A, Redler $\mathrm{S}$, et al. Genome-wide meta-analysis in alopecia areata resolves HLA associations and reveals two new susceptibility loci. Nat Commun 2015;6:5966.

28. Yang WL, Sharma A, Wang Z, Li Z, Fan J, Wang P. Coldinducible RNA-binding protein causes endothelial dysfunction via activation of Nlrp3 inflammasome. Sci Rep 2016; 6:26571.

29. Shin JM, Choi DK, Sohn KC, Kim SY, Ha JM, Lee YH, et al. Double-stranded RNA induces inflammation via the NF- $\kappa B$ pathway and inflammasome activation in the outer root sheath cells of hair follicles. Sci Rep 2017;7:44127. 